\title{
赤坂·六本木地区市街地再開発事業に伴う 我が国初の地下スタジオ
}

\author{
岩 永 志 昭*1 $\cdot$ 武 藤 光 $*^{2}$
}

\section{1.はじめに}

この再開発事業は，東京・港区赤坂六本木地区に扔け る民間組合による大規模再開発事業で, 昭和 46 年 3 月 に再開発適地調查が始まってから約 12 年の調査・計画 期間を経て，昭和 58 年 11 月に着工されたものである。 この地区は霞ケ関の中央官庁街や各国大使館む多く集ま り, 国際企業も軒を連ねている一方, 麻布・六本木の住 宅・商業地区にも隣接している。すなわち，国際的な政 治・経済の中枢機能が集約された高度なビジネス情報空 間と, 日常生活の場が有機的な結びつきをもった新しい 都市文化の創造を可能にする環境にある。

したがって, 地上 37 階建の事務所ビルや 36 階建て のホテルやコンサートホールに混じって，低層から 25 階の高層に至る住宅群がバランスよく配置されている。 その中心部に文化・情報の重要な担手となるべく, 我が 国初の地下式のテレビスタジオが完成した。

\section{2. 地下式スタジオの概要}

建物は丘陵地の斜面に立つ 6 階 建てで，高地部分に地上 2 階が顔 を出しているが，前面の 4 階部分 は，そっくり地下に入っている。 地上部分の屋上を含め, 建物の上 面は，ほとんどが広場として開放 されており，“一般に開かれた新 情報スタジオ”を志向するもので ある。そのために, 地上階の二ニ 一ススタジオでは，広場に集う 人々が，ガラスごしに放送現場を 直接見ることもできるようになっ

$* 1$ 清水建設 (株) 建築第一部 2 級 工事長

$* 2$ 清水建設 (株) 建築第一部工事 主任
ている。

地下には, 大小 3 つのスタジオがあり, 地上の騒音・ 振動にまったく影響されない環境で, 主として, 生放送 の番組が制作・放映される。地下式スタジオとすること で, 地震に強い, 遮音性にすぐれる, 保温性にすぐれる 等の放送スタジオとして多くのメリットがあるが，人の

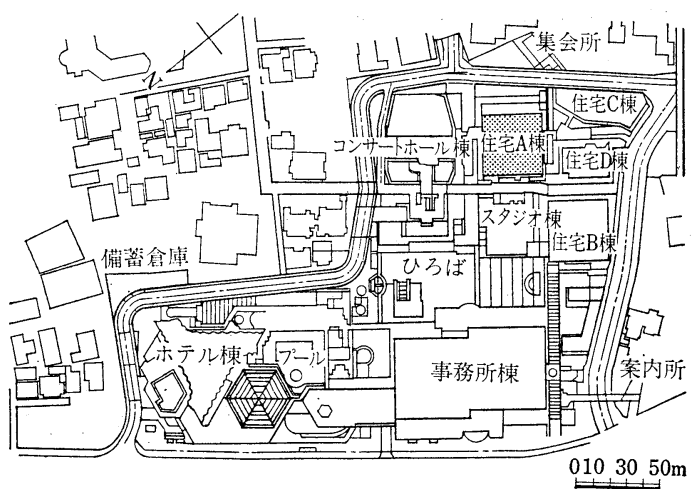

図一1 全体計画図

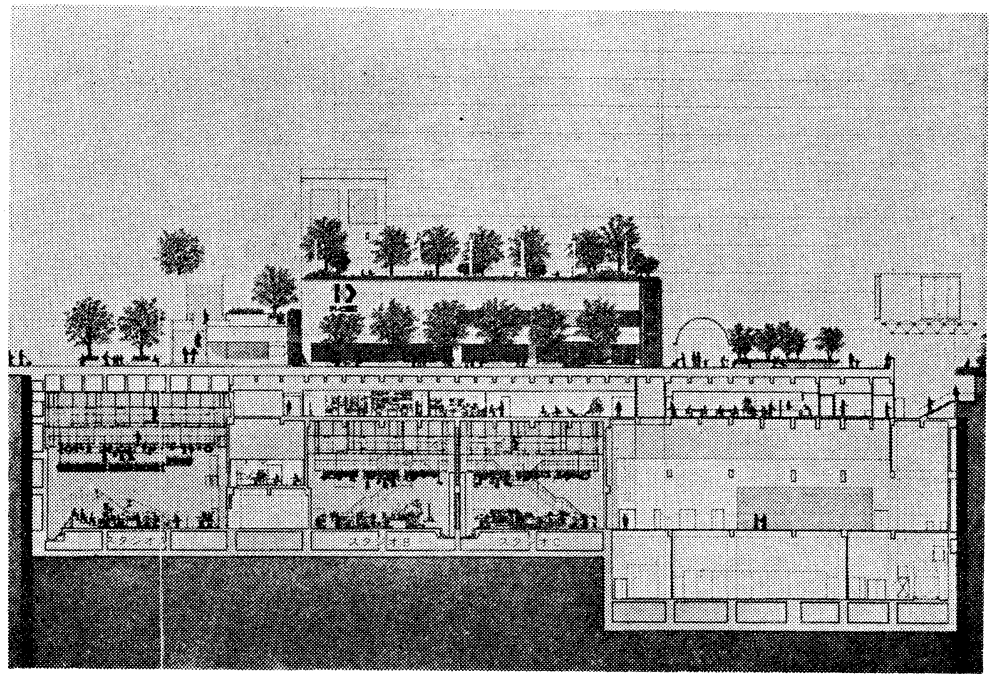

図一2 断 面 図 
多く集まる地下ロビー，食堂など には, 太陽光自動集光伝送装置に よって, 屋外で集めた自然光を直 接送り込んで生活環境の向上も図 っている。

また，防災関係については特に 注意をはらっている。すなわち， 消防法で定められた防災設備の外 に，非常用エレベータ（17 人乗 り)，全館にわたる 無線通信補助 装置, 非常用コンセント等を完備 している。また廊下の取り方, 階 段の位置について，いずれの方向 一避難しても自然に屋外一出られ るよう最も有効なレイアウトにな っている。

\section{3. 工 事 概 要}

\section{1 地下工事の計画之留意点}

都心の再開発事業の必然性か ら，敷地の最大限有効利用を図。 ているため, 各楝の地下躯体がほ とんど接する配置状態で計画され ている。各棟とも工事開始は同時 期であるが，躯体規模の違いによ り，地下工事工程が，それぞれ異 なる。その上スタジオ棟のみ他棟 より半年ほど短かい工期を設定さ れている。計画をたてるにあた り，上記の条件をふまえて，各棟 間との問題点を洗い出し，個々に 検討を加えて対策を立案した。

それらの問題のうち, 特に以下 の事項について留意して計画をた てた。

1）住宅棟側山止めは，地下が ないため, 地中連続壁+アー スアンカー工法とした。ただ し住宅棟はリバースぐいで建 物を支持する構造なので，く いを傷めない上う，〈い間に 精度良くアースアンカーを配 置して施工する計画とした。

2）コンサートホール棟側は， ホール棟の根切底のレベルが 高い上に，何種類にも分かれ ているため, 地中連続壁の施

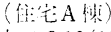
床付 $+9.10(10.10)$
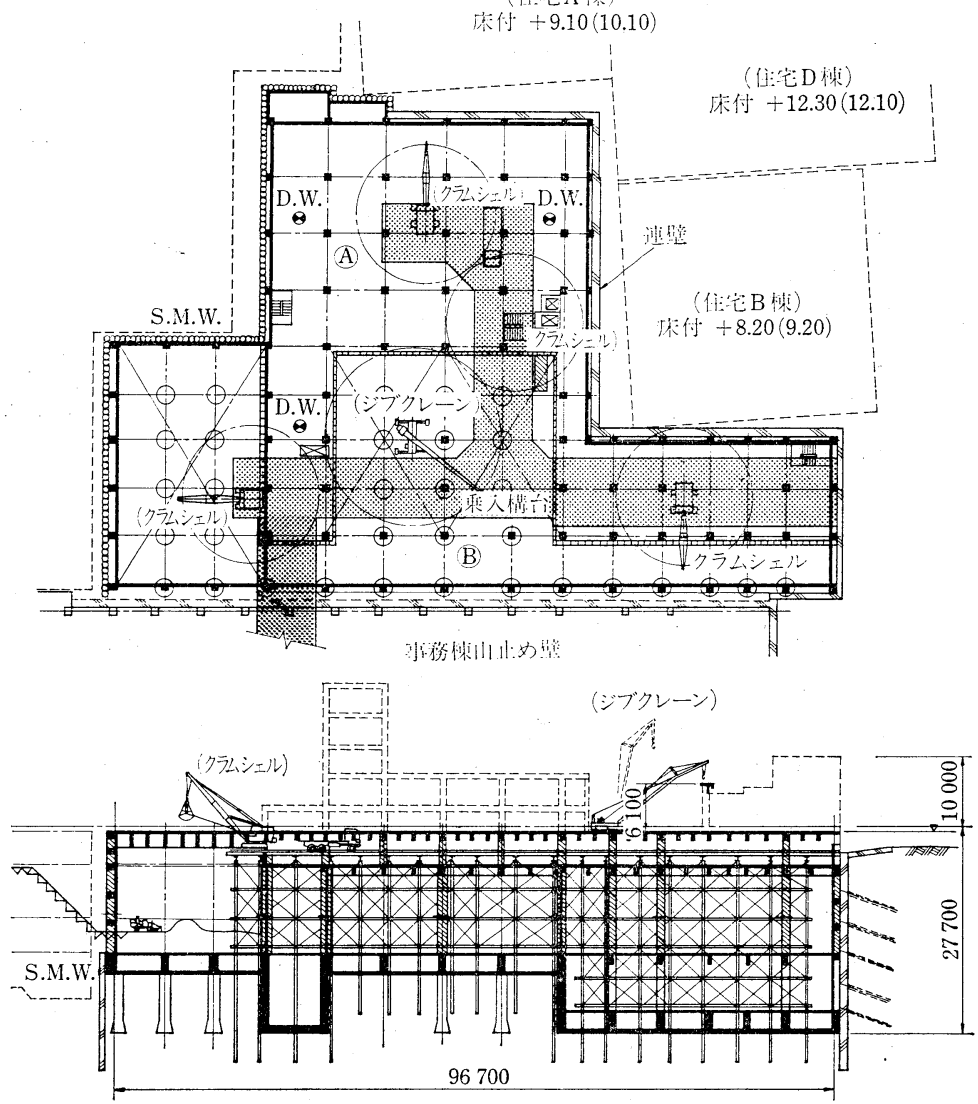

図一3地下施工計画
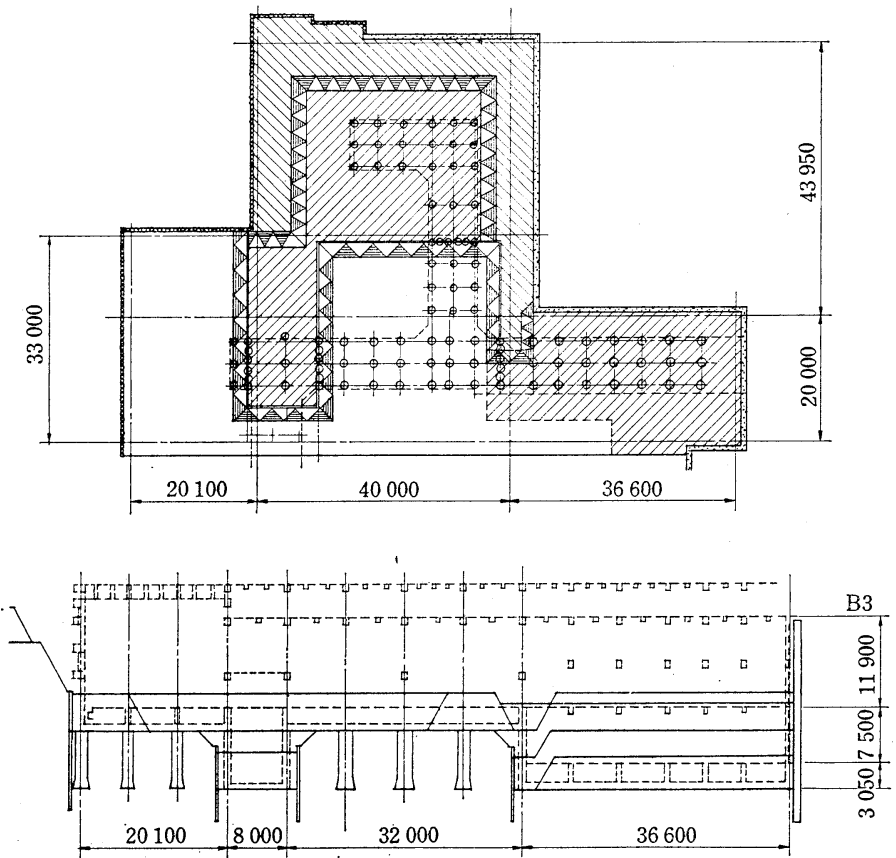

図一-4 根切計画図 
エができないので, SMW 山止壁+アースアンカー 工法とする。上部については, ホール棟側の根切工 程が遅いため, ホール棟敷地内に法面を切りながら 根切を進める計画とした。

3）事務所棟側については, 根切工程が同時期なの で，同時に根切を進めていくこととし，特殊な山止 め計画はしなかった。ただし床付部は約 $2.5 \mathrm{~m}$ 事 務所棟側が深いため, $\mathrm{H}$ 鋼十横矢板の自立式山止め を，事務所棟にて計画し施工することとした。

4）根切時の車両導線については, 出入口が場内の共 通仮設道路に面して 1 か所しかとれない状況の上 に, ホール棟, 住宅棟ともにその仮設道路を使用す るため, 朝のラッシュ時には相当な混雑が予想され た。そこで事務所棟に依頼して, 乗入構台を接続し てもらい，2方向の通路を確保することにより, 車 両の流れがスムーズになるよら計画した。

5）地下式のスタジオのため, 建物外周が全面外防水 となっている。従って躯体工事に先行して, 地中連 続壁面および SMW 山止壁面に防水を施工する必 要があった。工程が短い上に, 階高が高いので, 原 設計の熱アスファルト防水では施工性に問題が多い ため, 耐圧盤下はアスファルト系のシート防水, 壁 面はアスファルトゴム系吹付防水（プレノテクト防 水）への変更を計画し, 設計者の了解を得た。

6）地中連続壁および SMW 山壁面の躯体は防水層 の押えを兼ねているので，片押しの型わくになる。 階高が最高 7500 と高いことと, 山止壁面にセパレ 一タを取り付けた場合の防水層を傷つけることを避 けるため, 鉄骨支保工による片押し型わくを計画し た。その際の反力をとる方法として, 工程的に時間 のかかる外周部を残して, 中央部の躯体を 1 階分先 行させ, その先行させた躯体から反力をとる工法

\section{表一1 スタジオ棟の摡要}

\begin{tabular}{|c|c|}
\hline 工事名称 & $\begin{array}{l}\text { 赤坂六本木地区第一種市街地再開発事業スタジ } \\
\text { オ棟新築工事 }\end{array}$ \\
\hline 工事場所 & $\begin{array}{l}\text { 東京都港区赤坂 1-1314-1 外就よ゙六本木 1- } \\
\text { 41-13 }\end{array}$ \\
\hline $\begin{array}{l}\text { 発 注 者 } \\
\text { 設計監理 }\end{array}$ & $\begin{array}{l}\text { 赤坂六本木地区市街地再開発組合／森ビル(株) } \\
\text { 森ビル (株) /(株) 日建設計 }\end{array}$ \\
\hline 施 工 & 清水建設（株） \\
\hline 工 期 & 昭和 59 年 1 月～60 年 6 月 \\
\hline 延床面積 & $13604.09 \mathrm{~m}^{2}$ \\
\hline 広場面積 & R階 $927 \mathrm{~m}^{2}$, イベント広場 $2173 \mathrm{~m}^{2}$ \\
\hline 構造 & $\mathrm{SRC}$ 造, 一部 R C 造 \\
\hline 数 & 地下 4 階, 地上 2 階 \\
\hline 高 & $\begin{array}{lr}\text { 広場床レベル } & +8.35 \mathrm{~m} \\
\text { 広場床付レベル } & -28.20 \mathrm{~m}\end{array}$ \\
\hline 主要数量 & $\begin{array}{l}\text { 型わく } 80000 \mathrm{~m}^{2}, \text { コンクリート } 20780 \mathrm{~m}^{3} \\
\text { 鉄筋 } 3200 \mathrm{t} \text {, 鉄骨 } 700 \mathrm{t} \text {, 根切 } 88000 \mathrm{~m}^{3}\end{array}$ \\
\hline
\end{tabular}

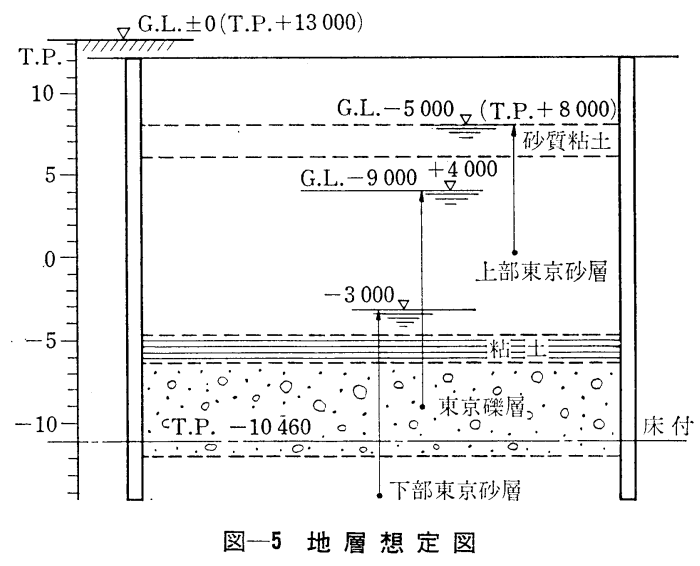

（アイランド工法と呼ぶ）を計画した。

結果的には上記の計画により施工を行い, 細部につい てはいろいろ問題もあったが，所定の工期で地下躯体を 完成させることができた。

\section{2 根切工事}

当現場の地盤について, ボーリング図を基に推定した のが図一5 である。上部東京砂層は $N$ 值 10 30 で, GL $-19.5 \mathrm{~m}$ ( TP $-6.5 \mathrm{~m})$ まで続いていて, 自由水 頭レベルは, GL $-5 \mathrm{~m}$ である。その下部の東京砅層は $N$ 值 50 以上で, $\mathrm{GL}-24 \mathrm{~m}$ の梁さまで続いていて, 被圧水頭は GL $-9 \mathrm{~m}$ と調查されている。

連続壁および SMW 壁は, 上部東京砂層および東京 䃯層の水を遮断する目的で $\mathrm{GL}-26 \mathrm{~m}$ まで打設する計 画とした。また，下部東京砂層にも GL $-16 \mathrm{~m}$ の被圧 水頭が計測されているので, ディープウェルを 3 基計画 して, 盤ぶくれ（被圧）に対処した。

(1) 地中連続壁

$\mathrm{BW}$ ロングウォールドリル工法により, 壁厚 $0.8 \mathrm{~m}$ と $1.0 \mathrm{~m}$, 延 $3500 \mathrm{~m}^{2}$ を, 実働 45 日 $\left(78 \mathrm{~m}^{2} /\right.$ 日) で施 工した。スタート時から天候に恵まれず，雪の中での厳 しい作業の連続であった。更にホール棟側の地山が，霊 南坂教会の移転の遅れにより一部残っていて, 泥水処理 プラントの配置に非常に苦労した。幸い事務所棟の協力 を得て，一部の敷地を借用し鉄筋加工場を設置させても ららことにより，機械台数をピーク時に 3 台に増やして 工程を消化した。

\section{(2) アースアンカー}

今回の再開発の地下工事については, 各棟とも工区境 の山止壁がないため, 外周については, すべてアースア ンカーにより山止壁を計画している。

スタジオ棟は, ロータリーパーカッション方式, 削孔 径 $100 \phi$, 総本数 180 本, 総延長 $3935 \mathrm{~m}$, 定着 VSL 工法にて施工した。最大設計荷重が $143 \mathrm{t}$ と非常に大き いため, ブラケットの強度および取付けが問題であっ 
た。ホールインアンカーでは耐力が不足なため，地中連 続壁の 施工時にブラケット取付用のプレートを埋め込 み，それに溶接で固定する方法を採用した。またアンカ 一撤去時の止水については, 防水モルタル注入後, ゴム パッキンと鉄板によるボルト締めおよび溶接の併用で止 水効果を衫らった。大部分が住宅棟のリバースぐいの間 を施工するため, 非常に厳しい精度を要求された。水平 精度がアンカー先端で $\pm 0.300 \mathrm{~m}$ であった。施工した 結果は，砂地盤の連続で施工性が良かったことと，作業 標準の徹底およびチェックリストの活用による, 細かい 品質管理により，全数要求された精度にて施工できた (図一6，写真一2 参照)。

(3) 計測管理

山止め面積が広いため, アースアンカーの支圧盤にセ ンターホールロードセルを組み込み, 事務所内に設置し た差動トランス測定器に接続して, 土圧の自動計測を実 施した。設置数は各段 5 か所で計 25 か所とし，それぞ れの数值をグラフ化して, 根切時の変動を確認しながら 工事を進めた。住宅棟リバースぐいについては, スタジ 才棟山止壁に近接している関係上, 特に設計事務所から その動きに注意するよう要望されているので，地中連続

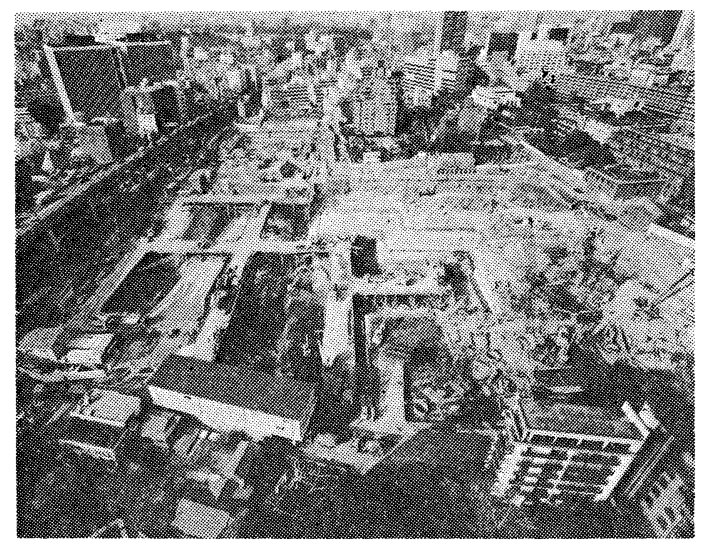

写真-1 全 景 (昭和 59 年 5 月撮影)

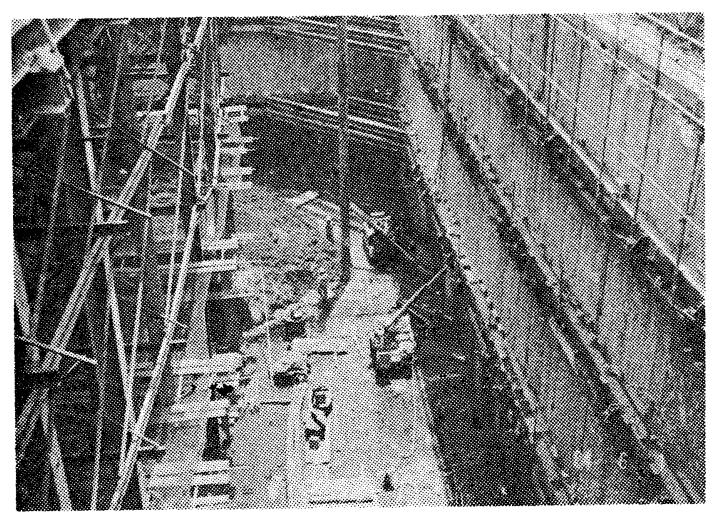

写真一2 住宅棟側 4 段目アースアンカー施工

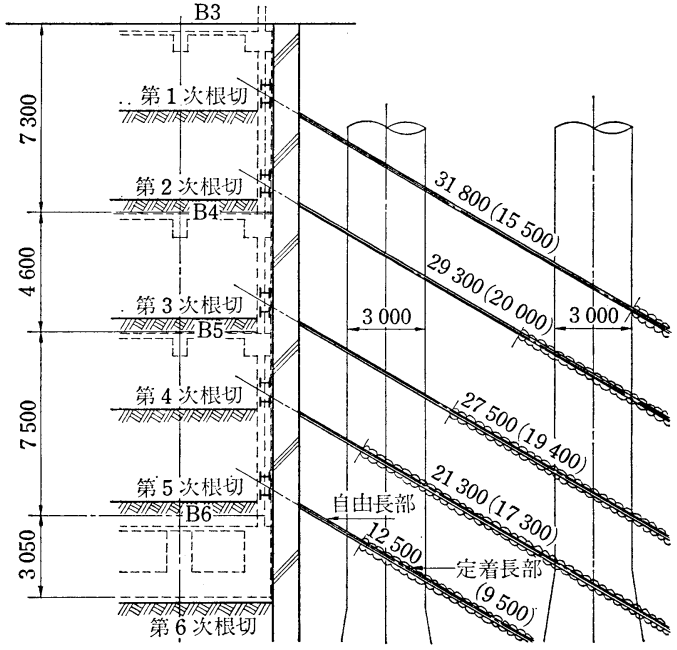

図一6 住宅棟側アースアンカー断面

壁とリバースぐいの 双方にローラー型傾斜計を埋め込 み，倒れの有無を計測管理した。

結果としては，土圧は設計荷重の 50〜75\% の範囲で 安定した動きを示した。また山止壁の倒れについても， 最大 $23 \mathrm{~mm}$ と予想を下回った数值でおさまった。なお 住宅楝のリバースぐいについても, 動きは認められなか った。

\section{3 アイランド式片押し型わく工法}

地下の躯体工事を進めていく上での最大の問題点は, 防水が施工してある山止め壁面に接している外周躯体の 型わく計画をどうするかということであった。階高が最 大 $7.500 \mathrm{~m}$, 壁厚 $1.000 \mathrm{~m}$ である。他現場の例を参考 にしながら，各種の計画を立案し検討してみた。

1）山止壁面に防水仕様のセパレータを取り付け, 壁 面の型わくを建て込む（セパレータのピッチが下部 で細かくなるため, 防水の補修が大変な上に文ず道 を作ることになるので，防水的にみて問題を残す)。

2) 斜めサポート形式で支保工を組み立て, 床にアン カー等を打ち込み反力をとる（側圧が大きすぎてサ ポートの部材が特殊になる上，床のアンカーボルト に全荷重がかかるので，危険である)。

3）壁の内部に [型鋼または $\mathrm{H}$ 鋼を埋め込み，上下で 固定した上，鋼材にセパレータを取り付け型わくを 組み立てる（鋼材が埋殺しになるのでコストが増大 する)。

4) 中央部の躯体を先行して打設する。山止め用の鋼 材 $(\mathrm{H}-300 \times 300)$ を利用した支保工を組み立て，中 央部の躯体から切ばり形式で上部を押さえる。コン クリート打設完了後, 型わくを解体し, 鋼材を揚重 機にて上階に引き上げて転用する（外周にダメ穴が 
残るが，鋼材は転用していくので，コスト的にメリ

ットが大きい，架構的にも安定している)。

上記の 4 案を検討した結果, コスト, 安全性, 防水性 等を考慮して第 4 案のアイランド形式の片押し型わく工 法を採用することにし，工事を実施した。

アイランド式片押し型わくの施工要領は以下のとおり である(図一7 参照)。

(1) 最下階のスラブコンクリート打設時に, 支柱の割 付図により，隅ピース取付用のアンカーボルト $22 \phi$ を埋め込む。

(2) 1 スパン内側の中央部躯体を先行して施工する。 支柱上部の押え用切ばり取付けのため, 中央躯体の, 外周部に, 受ピース用のアンカーボルト $22 \phi$ を埋 め込む。

(3) 山止め用の隅ピースを, 床に埋め込んだアンカー ボルトに固定する。取付けボルトに均等に荷重がか かるようにして締め付ける。

(4)、山止め用の $\mathrm{H}$ 鋼 $(\mathrm{H}-300 \times 300)$ をダブルに組んだ 支保工用の支柱を，揚重機で建て込む。

(5) 建て込んだ支柱の上部に横つなぎの $\mathrm{H}$ 鋼 $(\mathrm{H}-300$ $\times 300$ )を取り付ける。

(6) 中央部の躯体に隅ピースを取り付け, 頭押えの $\mathrm{H}$ 鋼 $(\mathrm{H}-300 \times 300)$ を継ぎ材と固定する。

(7) ベビーサポート (PS 6) を, 建て込んだ型わくと 支柱の間に取り付ける。サポートは $\mathrm{H}$ 鋼に固定した 足場板注釘打ちとする。

(8) 上階の取付用ボルトは, 下階の支柱位置の中間部 に埋め込む。

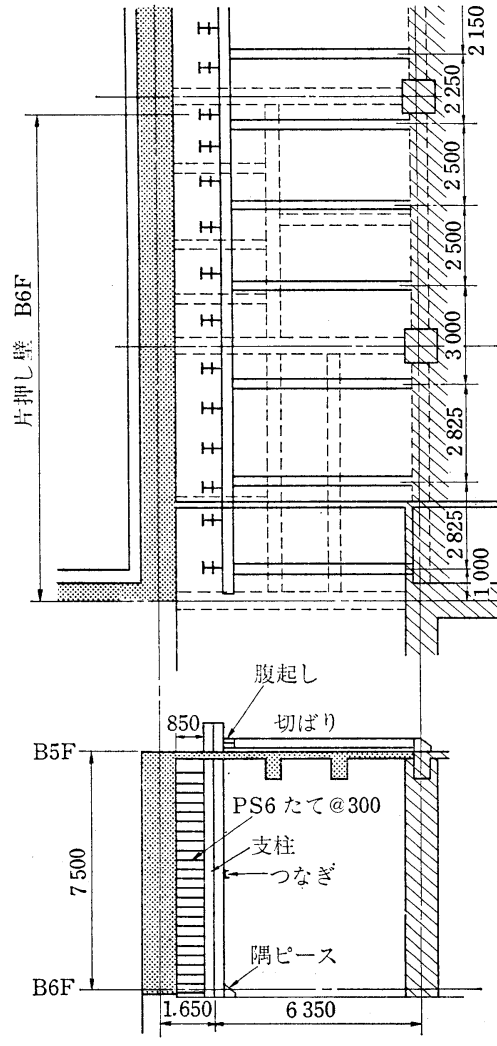

図一7 アイランド片押し型わく

上記要領で施工した結果としては，コンクリートの打 設時の型わくの動きは全く起こらず, 極めて安全な施工 ができた。

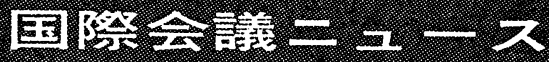

\section{建築における薄板鋼構造に関する国際コロキウム \\ Int. Colloquium on Thin-Walled Metal Structures in Buildings}

日 時: 1986 年 6 月 9 日 12 日

場 所: Stockholm (Sweden)

主 催: International Association for Bridge and Structural Engineering (IABSE)

内 容: The main themes of the Colloquium are: I. Thin-Walled Components, New Developments in Theory and PracticeMaterials, Sheet and Sections, Fasteners, Design Criteria, Coil Coating

II. Light-Gauge Metal Construction and Building Systems-Roofs, Walls, Floors, Building Systems, Erection
iII. Composite Light-Gauge Metal Construction-Materials, Connections, Design, Structural Behaviour

IV. Building Physics in Light-Gauge Metal Construction-Thermal Insulation, Weatherproofing, Air Tightness, Acoustics and Vibrations, Fire Resistance, Durability

連絡先: IABSE Colloquium, c/o RESO Congress Service, S-113 92 Stockholm, Sweden 